\section{Tercentenary of Jeremiah Horrocks}

ON January 3 occurred the tercentenary of the death of the young Lancashire curate Jeremiah Horrocks, whom Herschel spoke of as the pride and boast of British astronomy. In the fourteenth year of the reign of Charles $I$, and some twenty years before the foundation of the Royal Society, in the hamlet of Toxteth Park near Liverpool and in the village of Hoole, eight miles south of Preston, Horrocks, with the aid of the tables of Lansberg and the works of Kepler, recalculated the transit of Venus and, on Sunday afternoon, November 24, I639, in between his church services at Hoole, had the great satisfaction of watching the passage of the planet across the sun's disk. His friend, William Crabtree, also observed the transit from near Manchester, but Horrocks's brother Jonas, at Liverpool, failed to see it owing to clouds. Within fourteen months of his achievement, Horrocks had passed away, being then but twenty-two or twenty-four years of age. He had, however completed his "Venus in Sole Visa".

Though he made his observations at Hoole, Horrocks passed most of his life at Toxteth Park, save for the three years 1632-35, which he spent as an undergraduate at Emmanuel College, Cambridge. The site of the house he was born in is now covered by the Otterspool Railway Station; his grave is in the grounds of the ancient chapel of Toxteth, a place of worship associated with the early Dissenters. Not far away is the Church of St. Michael's, and here in 1826, the Lancashire gardener-weaver-astronomer Moses Holden (1777-1864) erected the first memorial to Horrocks. In 1859 the Rev. A. B. Whatton published a translation of his "Venus in Sole Visa", together with a memoir of Horrocks; a memorial chapel and window were added in the same year to Hoole church, and when attention was again being directed to Horrocks's work by the transit of Venus of 1874, steps were taken to place a memorial in Westminster Abbey.

On November 12, 1874, Nature recorded the permission given for the erection of this memorial, and a list of subscribers, headed by the names of Adams and Airy and including those of Christie, De la Rue, Lassell, Lockyer, Proctor, and "the Village of Hoole". The memorial in the Abbey, unveiled in 1879, consists of a scroll placed within the monument to John Conduitt, the nephew of Newton, at the west end of the nave. Owing to Horrocks's premature death, and the confusion of the times, some of Horrocks's manuscripts were lost. That of the "Venus in Sole Visa" was saved, and a copy passed to Huygens and then to Hevelius, who published it in 1662. Other manuscripts were published by John Wallis in 1673, and these showed that Horrocks had views on many subjects far in advance of his time. In Manchester Town Hall there is a fresco by Madox Brown recalling the observation of the transit of 1639 , but in this the scene is Manchester and the central figure is Crabtree.

\section{Psychology of Joan of Arc}

IN a paper entitled "A Medico-psychological Revision of the Story of Jehanne La Pucelle" read before the Section of the History of Medicine of the Royal Society of Medicine on December 4, Dr. H. P. Bayon said that modern historians, by interpreting medieval religious conceptions according to the dic. tates of contemporary critical doctrines, have failed to examine the voices and visions of La Pucelle in their proper light and sequence. The first voices heard at the age of thirteen were, according to him, connected with endocrine activity tinged by intense religious fervour and could not be rightly diagnosed as morbid, even if they ranked as somewhat abnormal. A couple of years after, the simple monitions of the voices were followed by visions and commands, directing the Maid to perform valiant military deeds for a patriotic service; these must be classified as something additional, since their purpose was creative and constructive and furthered the accomplishment of a certain preconceived plan by providing eonfidence in her mission and obtaining authority for her message. Joan of Arc thus became instinctively the first protagonist of that form of national patriotism which was to play such a part in arranging States and dynasties in Europe during succeeding centuries.

Her courage and perseverance could be matched by other heroines in history; the boldness of her patriotic conceptions was unique, not only for her age and sex, but also because of her youth and lack of military education. In constructive leadership she far surpassed Christine de Pisan, who had full opportunities for obtaining the knowledge requisite in formulating the teachings of French nationalism. Fven if her voices and visions were diagnosed as hallucinations, there was no reason to consider these as part of a system of morbid delusions. Not only their form and content but also her subsequent behaviour provided full evidence that she conceived, planned, and put into execution a programme of national survival which obtained historical significance. Such achievements could not be the outcome of the wild vapourings of insanity; they must be the work of creative genius.

\section{Chemistry at St. Andrews}

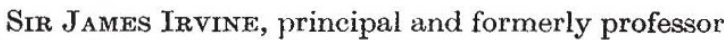
of chemistry of the University of St. Andrews, reviewed the history of chemical teaching at the University in an address on December 6 before the University of St. Andrews Chemical Society. The story goes back, Sir James said, to 1808, when the University accepted a gift of $£ 1,500$ from Dr. John Gray, of Paddington, to institute and maintain a chair of chemistry at St. Andrews. This sum was totally inadequate to found the chair, and no appointment was actually made until 1840. While Sir David Brewster was principal of the University, the endowment was brought up to $£ 2,700$, and Dr. Arthur Connell was appointed the first professor of chemistry. Connell, who became an authority on mineral analysis, was succeeded in 1862 by Prof. Matthew Forster Heddle. Heddle devoted his attention chiefly to mineralogy; among his students were James Stuart, afterwards the first professor of engineering at Cambridge, Francis Robert Japp, who became professor 